\title{
The Warring Brothers: Borges Reads Kafka and Flaubert
}

\author{
Daniel Balderston ${ }^{1}$
}

This article examines the preparatory materials that Borges used to teach courses at the Colegio Libre de Estudios Superiores in Buenos Aires, on Kafka in 1951 and on Flaubert in 1952. Though several well known essays emerged from these courses - "Kafka y sus precursors", "Flaubert y su destino ejemplar" and "Vindicación de Bouvard et Pécuchet" - the manuscripts reveal far more of Borges's research and thinking about the two authors. Key concepts that he develops in these essays include his unusual (and influential) idea of the "precursor" that is only revealed through reading later works and heterodox ideas about realism and verisimilitude. [Article copies available for a fee from The Transformative Studies Institute. E-mail address: journal@transformativestudies.org Website: http://www.transformativestudies.org (C2020 by The Transformative Studies Institute. All rights reserved.]

KEYWORDS: Borges, Flaubert, Kafka, Verisimilitude, Colegio Libre de Estudios Superiores, Courses, 1951, 1952, Manuscripts.

In the early 1950 s Borges taught a series of courses, and gave talks, at the Colegio Libre de Estudios Superiores, an institution that had been founded in 1930 just before the coup d'état against Hipólito Yrigoyen and that during what is usually called "el primer peronismo," the presidential terms of Juan Domingo Perón from 1946 to 1955, served as a sort of open university. Three of his talks there were published at the time in the Colegio's magazine, Cursos y Conferencias, while some were

\footnotetext{
${ }^{1}$ Daniel Balderston is Andrew W. Mellon Professor of Modern Languages at the University of Pittsburgh, where he directs the Borges Center; he is the editor of Variaciones Borges. Before coming to Pittsburgh, he taught at Tulane and the University of Iowa. His research focuses on Borges and his contemporaries (Onetti, Silvina Ocampo, Roa Bastos) and writers whose work responds in different ways to Borges's work (Wilcock, Piglia, Saer). He also works on gender and sexuality studies and in literary translation (and in translation studies). His work ranges across Spanish America and Brazil, with a particular emphasis on the River Plate area. His most recent book on Borges, titled How Borges Wrote, was published in 2018. He has edited numerous books, including Voice-Overs: Translation and Latin American Literature, and has also translated books by José Bianco, Juan Carlos Onetti, Sylvia Molloy, and Ricardo Piglia. Address correspondence to: Daniel Balderston; e-mail: Daniel.Balderston@pitt.edu.
} 